\title{
Medical Product Document
}

National Cancer Institute

\section{Source}

National Cancer Institute. Medical Product Document. NCI Thesaurus. Code C54693.

A document defining content and form of the information that has to be supplied with or about a medical product by or on behalf of the marketing authorization holder. 